\title{
Bentuk Makam-Makam Belanda Di Cilacap Dan Purworejo
}

\section{Muhammad Chawari}

Keywords: kerkhoff, typology, distribution, java, description, tomb, dutch

\section{How to Cite:}

Chawari, M. (2003). Bentuk Makam-Makam Belanda Di Cilacap Dan Purworejo. Berkala Arkeologi, 23(1), 102-108. https:// doi.org/10.30883/jba.v23i1.865

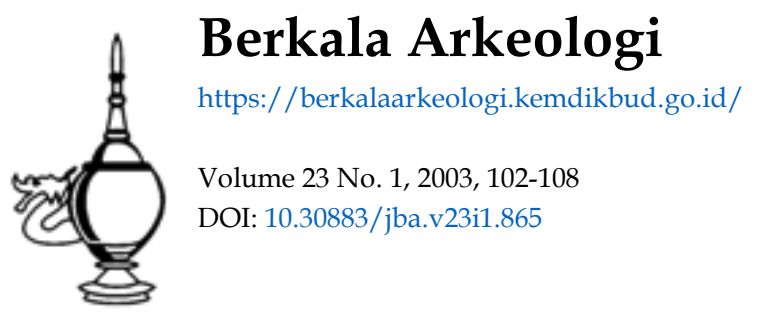

\section{c) (1) (5)}

This work is licensed under a Creative Commons Attribution-NonCommercial-ShareAlike 4.0 International License. 


\title{
BENTUK MAKAM-MAKAM BELANDA DI CILACAP DAN PURWOREJO
}

\author{
Muhammad Chawari
}

\section{$\mathbf{P}$}

\section{ENDAHULUAN}

Seperti halnya dengan kota-kota lain di Jawa Tengah, Cilacap dan Purworejo juga pernah mengalami pendudukan Belanda. Cilacap bahkan dikembangkan oleh Belanda menjadi pelabuhan terbesar keempat di Jawa, setelah Batavia, Surabaya, dan Semarang (Zuhdi, 2002). Sementara Purworejo dikenal sebagai semacam "kota militer" bagi Belanda (Musadad, 2001). Dengan demikian di kedua kota ini banyak dijumpai peninggalan-peninggalan arkeologis yang menunjukkan pengaruh Belanda, antara lain berupa benteng, tempat tinggal (rumah), perkantoran, gudang, dan gereja.

Daerah Cilacap pernah diteliti oleh Balai Arkeologi Yogyakarta, yaitu dalam rangkaian penelitian Survei Sarana Pertahanan Kolonial Tahap III. Hasil yang didapat di daerah Cilacap berupa Benteng Pendem, Benteng Karangbolong, dan Mercu Suar Cimiring (Abbas, 1995/1996). Menyangkut Purworejo, daerah ini pernah diteliti untuk keperluan pembuatan tesis, terutama yang menyangkut perubahan tata ruang kota (Musadad, 2001).

Tulisan tentang bentuk-bentuk makam Belanda ini berdasarkan atas penelitian Keletakan dan Bentuk-bentuk Makam Belanda di Jawa Tengah Tahap IV. Menyangkut penelitian yang sama yang dilaksanakan pada tahap-tahap sebelumnya (Tahap I s.d. III) di sejumlah kota di Jawa Tengah dan Jawa Timur (Chawari, I998/1999, 1999/2000, 2000), hasil penelitiannya menunjukkan adanya sejumlah variasi bentuk makam Belanda, mulai dari yang sederhana hingga yang rumit dan raya akan hiasan. Bentuk sederhana pada umumnya berupa empat persegi panjang dengan epitaph di atasnya, sementara makam yang rumit dan raya akan hiasan, berbentuk menyerupai rumah dan tugu dengan berbagai ornamentasinya.

Keberadaan bangsa Belanda di Indonesia, khususnya di Jawa, selama kurang lebih 3,5 abad, tentu meninggalkan berbagai jejak dan pengaruh. Hal ini dapat dilihat antara lain dari keberadaan bangunan-bangunan kolonial di berbagai kota. Bangunanbangunan tersebut dapat dibedakan menjadi bangunan-bangunan yang bersifat pribadi (misalnya bangunan tempat tinggal) dan bangunan-bangunan yang bersifat umum (misalnya bangunan kantor, gereja, dan makam). Menyangkut bangunan makam, objek tersebut berbeda dengan makam pribumi pada umumnya. Pada makam pribumi, yang pada umumnya berlatar belakang agama Islam, pemberian tanda pada makam bersifat sederhana, sebatas untuk menunjukkan tanda pada bagian kepala dan 
kaki orang yang dimakamkan. Sementara itu makam Belanda secara fisik menunjukkan berbagai variasi dari yang sederhana hingga yang megah, besar, dan raya dengan berbagai ornamentasinya.

Berkaitan dengan makam-makam Belanda di Indonesia (khususnya di Jawa) tersebut telah menemukan banyak sekali data, yaitu: nama orang yang dimakamkan, tempat kelahiran dan kematian, pertanggalan, jabatan, dan beberapa bacaan yang erat kaitannya dengan silsilah keluarga. Sementara itu, penelitian tentang makam-makam Belanda yang ada di Indonesia belum banyak dilakukan. Kalaupun ada kebanyakan makam-makam Belanda disebut hanya sebagai pelengkap dalam sebuah kajian yang lebih kompleks. Berkaitan dengan bangunan yang berupa makam tersebut belum banyak diteliti. Walaupun sebenarnya dari segi kuantitas cukup banyak ditemukan diberbagai daerah, mengingat keberadaan bangsa Belanda di Indonesia berlangsung cukup lama. Berdasarkan latar belakang masalah tersebut, muncullah sebuah permasalahan yaitu bagaimanakah bentuk makam orang-orang Belanda yang ada di Indonesia.

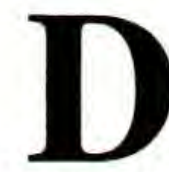

\section{ATA DARI MASING-MASING SITUS} I. Kotamadia Cilacap

Secara administratif kompleks makam Belanda (kerkhof) terletak di Dusun Kebonjati, Kelurahan Kebonjati, Kecamatan Cilacap Selatan. Makam Belanda yang terdapat di daerah ini seluruhnya berjumlah 268 buah makam. Dari jumlah tersebut dapat dikelompokkan menjadi dua (2), yaitu rebah dan berdiri. Masing-masing kelompok memiliki sejumlah variasi bentuk, yaitu:

A. Kelompok rebah merupakan bentuk makam yang nisannya dibuat dari lempengan batu besar berbentuk empat persegi panjang yang direbahkan hampir rata dengan permukaan tanah. Nisan tersebut dibuat dari susunan bata berspesi yang ditinggikan beberapa puluh $\mathrm{cm}$ di atas permukaan tanah. Jumlah makam dalam kelompok ini ada 188 buah makam dari jumlah temuan keseluruhan. Secara fisik tersaji dalam 4 bentuk makam, yaitu:

- Makam yang dibuat dari susunan bata berspesi, di mana pada bagian atas hampir datar. Selanjutnya pada bagian kepala lebih tinggi dari pada bagian kaki. Tinggi makam dari permukaan tanah sekitarnya berkisar antara 114 $128 \mathrm{~cm}$. Makam berbentuk seperti ini seluruhnya berjumlah I57 buah.

- Makam yang dibuat dari susunan bata berspesi, di mana pada bagian atas diberi lobang berbentuk empat persegi panjang. Kemudian pada bagian atas (kepala) sepanjang $48 \mathrm{~cm}$ ditinggikan rata-rata $52 \mathrm{~cm}$. Makam berbentuk seperti ini seluruhnya berjumlah 21 buah.

- Makam yang dibuat dari susunan bata berspesi, di mana pada bagian atas ditinggikan, yaitu bagian tengah lebih tinggi dari pada kedua sisi yang lain 
secara lurus. Bagian yang ditinggikan rata-rata $34 \mathrm{~cm}$. Makam berbentuk seperti ini seluruhnya berjumlah 7 buah.

- Makam yang dibuat dari susunan bata berspesi, di mana pada bagian atas ditinggikan, yaitu bagian tengah lebih tinggi dari pada kedua sisi yang lain secara lengkung setengah lingkaran. Bagian yang ditinggikan rata-rata 112 $\mathrm{cm}$. Makam berbentuk seperti ini seluruhnya berjumlah 3 buah.

B. Kelompok berdiri, terdiri atas bentuk tugu dan bentuk mausoleum. Bentuk tugu adalah bentuk makam yang pada bagian dasar persegi, sedangkan bagian atas berbentuk bulat dan persegi. Dalam pembuatannya, bentuk ini meliputi berbagai ukuran, variasi, dan ornamennya. Salah satunya yang paling "monumental" adalah makam berbentuk tugu yang nisannya ditinggikan $335 \mathrm{~cm}$ dan pada bagian atasnya merupakan bentuk piala. Bentuk yang sama dengan ukuran lebih kecil tingginya tidak mencapai 1 meter dan tanpa variasi maupun ornamen lain. Makam berbentuk seperti ini seluruhnya berjumlah 80 buah. Sementara makam dengan bentuk mausoleum yaitu merupakan makam yang bentuknya menyerupai bangunan rumah. Bentuk ini mempunyai ketinggian $228 \mathrm{~cm}$ dan pada bagian atas rata atau horisontal. Makam dengan bentuk seperti ini hanya ada 1 buah.

\section{Kabupaten Purworejo}

Secara administratif kompleks makam Belanda (kerkhof) terletak di Kampung Nguapasan I, Kelurahan Sindurejan, Kecamatan Purworejo. Makam-makam Belanda yang terdapat di daerah ini seluruhnya berjumlah 225 buah makam. Dari jumlah tersebut dapat dikelompokkan menjadi dua bentuk yaitu rebah dan berdiri. Masingmasing kelompok memiliki sejumlah variasi bentuk, yaitu :

A. Kelompok rebah merupakan bentuk makam yang nisannya dibuat dari lempengan batu besar berbentuk empat persegi panjang yang direbahkan hampir rata dengan permukaan tanah. Nisan tersebut dibuat dari susunan bata berspesi, di mana pada bagian atas hampir datar. Kemudian pada bagian kepala lebih tinggi dari pada bagian kaki. Selanjutnya bentuk ini meliputi berbagai ukuran dan variasi. Salah satunya yang paling "monumental" adalah makam yang nisannya (bagian kepala dan kaki) ditinggikan antara $120-140 \mathrm{~cm}$. Makam berbentuk seperti ini seluruhnya berjumlah 142 buah makam.

B. Kelompok berdiri, terdiri atas bentuk tugu dan bentuk mausoleum. Bentuk tugu adalah bentuk makam yang pada bagian dasar persegi, sedangkan bagian atas berbentuk bulat dan persegi. Dalam pembuatannya, bentuk ini meliputi berbagai ukuran, variasi, dan ornamennya. Bentuk imi berdasarkan ukuran ketinggian berkisar antara $146-448 \mathrm{~cm}$. Sementara itu makam dengan bentuk seperti ini berdasarkan variasi dan ornamen meliputi bagian atas menyerupai bentuk jam, 
bagian atas seperti stupa, dan bagian atas kerucut. Makam berbentuk seperti ini seluruhnya berjumlah 79 buah. Sedangkan makam dengan bentuk mausoleum yaitu merupakan makam yang bentuknya menyerupai bangunan rumah. Bentuk ini mempunyai ketinggian $220 \mathrm{~cm}$ dan pada bagian atas rata atau horisontal. Makam dengan bentuk seperti ini hanya ada 4 buah.

Dengan demikian berdasarkan bentuk fisik, secara umum dapat dikatakan bahwa makam-makam Belanda mempunyai dua bentuk dasar yang baku yaitu rebah dan berdiri. Masing-masing bentuk tersebut mempunyai variasinya sendiri-sendiri. Salah seorang ahli berpendapat bahwa makam-makam Belanda dibuat dalam tiga bentuk, yaitu: pertama, lempengan batu besar (epitaph) yang direbahkan hampir rata dengan permukaan tanah; kedua, lempengan batu (epitaph) yang ditempelkan pada struktur lain dan dibuat dari bata berperekat; dan ketiga, makam yang diletakkan di bawah mausoleum (dengan bangunan tambahan) (Rea, 1897). Kedua bentuk makam Belanda yang terdapat di Cilacap dan Purworejo tersebut jika dikaitkan dengan pendapat Rea dapat dibagi menjadi dua, yaitu:

1. Bentuk rebah, merupakan bentuk dari lempengan batu besar (epitaph) yang direbahkan hampir rata dengan permukaan tanah. Dalam perkembangannya, bentuk ini kemudian ditinggikan beberapa puluh $\mathrm{cm}$ di atas permukaan tanah.

2. Bentuk berdiri, merupakan bentuk dari lempengan batu (epitaph) yang ditempelkan pada struktur lain dan dibuat dari bata berperekat, serta makam yang diletakkan di bawah mausoleum (dengan adanya bangunan tambahan).

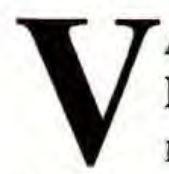

\section{ARIASI BENTUK MAKAM BELANDA}

Makam-makam Belanda yang terdapat di Cilacap dan Purworejo sudah mengalami banyak kerusakan, terutama dengan hilangnya sejumlah makam dan prasasti (epitaph). Keadaan ini disebabkan makam-makam tersebut telah berusia tua. Kerusakan yang diakibatkan ulah manusia merupakan bentuk pengrusakan yang paling besar. Hal ini membuat makam-makam sebagian besar menjadi tidak utuh lagi. Selain itu, menyempitnya lokasi pemakaman karena adanya perluasan lokasi permukiman warga sekitar kompleks makam juga membuat hilangnya sejumlah makam Belanda. Oleh karena tu, analisis terhadap bentuk makam Belanda dilakukan berdasarkan data fisik makam-makam yang masih tersisa. Data fisik yang dimaksud adalah berupa bangunan makam itu sendiri.

Pada dasarnya makam-makam Belanda yang terdapat di Indonesia - khususnya di Cilacap dan Purworejo - mempunyai bentuk khusus yang berbeda dengan makammakam pribumi pada umumnya. Makam-makam Belanda yang terdapat di Cilacap dan Purworejo mempunyai bentuk dasar yang sama. Kesamaan bentuk dasar tersebut dapat dilihat dari denah makam yaitu bujur sangkar dan empat persegi panjang. Dari bentuk dasar tersebut kemudian dikembangkan menjadi beberapa bentuk yang 
berbeda-beda, baik pada kompleks makam yang sama maupun antar kompleks makam. Pada masing-masing lokasi, bentuk yang dikembangkan menunjukkan adanya ketidaksamaan. Hal ini dapat diketahui bahwa pada satu kompleks makam, bentuk-bentuk yang dikembangkan mempunyai jumlah yang lebih banyak dari pada kompleks makam yang lain.

Selanjutnya dapat dikatakan bahwa pendapat Rea (Rea, 1897) yang membagi bentuk makam Belanda ke dalam 3 kelompok seperti tersebut di atas pada dasarnya tidak dapat diterapkan pada makam-makam Belanda yang menjadi objek penelitian di Cilacap dan Purworejo. Hal ini mengingat bahwa pendapat Rea tersebut tidak konsisten dalam melakukan pengelompokan terhadap makam-makam yang ada. Ketidak konsistenan Rea terlihat yaitu mencampuradukkan antara epitaph dengan bangunan makam. Jelasnya sebagai berikut: kelompok I dan II berkaitan dengan epitaph, dikatakan bahwa lempengan batu besar (epitaph) yang direbahkan hampir rata dengan permukaan tanah dan lempengan batu (epitaph) yang ditempelkan pada struktur lain yang dibuat dari bata berperekat. Kelompok III adalah makam yang diletakkan di bawah mausoleum (dengan bangunan tambahan). Sementara itu pengelompokan pada makam-makam Belanda hasil penelitian ini hanya didasarkan atas bentuk fisik bangunan makam itu sendiri, yaitu kelompok rebah dan kelompok berdiri. Masing-masing kelompok mempunyai variasi, terutama yang berkaitan dengan ukuran dan raya tidaknya ornamen yang menyertainya.

Mengingat hal tersebut, makam-makam Belanda hasil penelitian ini tidak dapat sepenuhnya berkiblat pada pengelompokan yang telah dilakukan oleh Rea. Oleh karena itu pendapat tersebut dipandang sebagai bahan masukan dalam pengelompokan makam-makam Belanda hasil penelitian ini.

\section{TAKTOR-FAKTOR YANG BERPENGARUH TERHADAP BENTUK MAKAM BELANDA}

Pada dasarnya makam-makam Belanda yang terdapat di Cilacap dan Purworejo mempunyai 2 bentuk dasar yang berbeda satu dengan lainnya, yaitu rebah dan berdiri. Dari kedua bentuk dasar tersebut masing-masing kelompok memiliki sejumlah variasi bentuk yang berbeda-beda, baik pada kompleks makam yang sama maupun antar kompleks makam.

Bentuk makam Belanda yang terdapat di Kotamadia Cilacap ada 2 kelompok, yaitu rebah dan berdiri. Kelompok rebah dengan 4 variasi, yaitu bagian atas horisontal, bagian atas diberi lobang, bagian tengah atas lebih tinggi dari pada dua sisi lainnya, dan bagian atas berbentuk lengkung setengah lingkaran. Kelompok berdiri dengan 2 variasi, yaitu bentuk tugu dan mausoleum. Sementara di Purworejo terdapat 2 kelompok, yaitu rebah dan berdiri. Kelompok rebah dengan sebuah variasi, yaitu 
bagian atas horisontal. Kelompok berdiri dengan 2 variasi, yaitu bentuk tugu dan bentuk mausoleum.

Dari berbagai bentuk makam Belanda seperti tersebut di atas, yang menyebabkan timbulnya berbagai variasi lebih cenderung diakibatkan oleh kemampuan orang tersebut (yang meninggal) dalam menampilkan bentuk makam yang diinginkan. Semakin mampu (baca: kaya) seseorang, bentuk makamnya semakin besar, megah, dan raya akan hiasan. Sebaliknya seseorang yang kurang atau tidak mampu, akan menampilkan bentuk makam yang kecil dan sederhana tanpa banyak hiasan yang menyertainya. Keadaan seperti tersebut berlaku secara umum, sebab ada juga makam Belanda yang menampilkan bentuk tugu yang berukuran kecil tanpa adanya hiasan yang menyertainya. Misalnya makam Belanda berbentuk tugu yang terdapat di Kecamatan Pamotan, Kabupaten Rembang, serta beberapa makam Belanda berbentuk tugu yang terdapat di Cilacap dan Purworejo. Sementara itu ada pula makam Belanda yang menampilkan bentuk rebah dengan variasi empat persegi panjang dengan bagian atas horisontal yang dibuat lebih "monumental" dengan ukuran tinggi antara 120 $140 \mathrm{~cm}$.

Dengan demikian bentuk makam Belanda berkaitan erat dengan kemampuan (baca: kaya) seseorang untuk menampilkan bentuk makam yang diinginkan. Secara umum ukuran mampu seseorang berbanding sejajar dengan jabatan yang diembannya. Semakin tinggi jabatan seseorang semakin kaya orang tersebut.

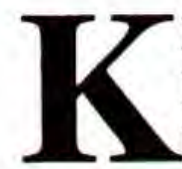

\section{ESIMPULAN}

Makam-makam Belanda yang terdapat di Indonesia - khususnya Jawa, lebih Bentuk-bentuk pribumi pada umumnya. Perbedaan tersebut tidak hanya pada bentuk makam, tetapi juga ukuran, dan variasinya. Dengan mempelajari bentuk-bentuk makam Belanda tersebut dapat diketahui latar belakang adanya perbedaan bentuk makam antara satu individu dengan individu yang lain dalam masyarakat Belanda di Indonesia.

Berdasarkan penelitian Bentuk dan Keletakan Makam-makam Belanda Pada Kotakota di Jawa Tengah Tahap IV yaitu di Kotamadia Cilacap dan Kabupaten Purworejo dapat dikemukakan hal-hal sebagai berikut:

1. Berdasarkan penelitian makam-makam Belanda di Kotamadia Cilacap dan Kabupaten Purworejo dapat dikatakan bahwa terdapat 2 kelompok besar bangunan makam Belanda, yaitu rebah dan berdiri. Kelompok rebah mempunyai bentuk dasar empat persegi panjang dengan variasi bersifat sederhana. Kelompok berdiri terdiri atas bentuk tugu dan bentuk mausoleum - pada umumnya mempunyai bentuk yang besar, rumit, dan kaya akan hiasan. 
2. Perbedaan bentuk makam Belanda berkaitan erat dengan kemampuan (baca: kaya) seseorang. Kemampuan atau kekayaan seseorang berbanding sejajar dengan jabatan yang diembannya, yaitu semakin tinggi jabatan seseorang semakin kaya orang tersebut.

\section{KEPUSTAKAAN}

Abbas, Novida. 1995/1996. Laporan Hasil Penelitian Arkeologi Survei Sarana Pertahanan Kolonial di Kotamadia Pekalongan, Kabupaten Kebumen, dan Kotamadia Cilacap, Provinsi Jawa Tengah (Tahap III). Yogyakarta: Balai Arkeologi.

Chawari, Muhammad. 1998/1999. Laporan Penelitian Arkeologi, Keletakan dan Bentuk-bentuk Makam Belanda Pada Kota-kota Pantai (Tahap I). Yogyakarta: Balai Arkeologi.

1999/2000. Laporan Penelitian Arkeologi, Keletakan dan Bentukbentuk Makam Belanda Pada Kota-kota Pantai (Tahap II). Yogyakarta: Balai Arkeologi.

2000. Laporan Penelitian Arkeologi, Keletakan dan Bentuk-bentuk Makam Belanda Pada Kota-kota Pantai (Tahap III). Yogyakarta: Balai Arkeologi.

Musadad. 2001. Dari Permukiman Benteng Ke Kota Administrasi (Tata Ruang Kota Purworejo Tahun 1831 - 1930). Yogyakarta: Thesis pada Universitas Gadjah Mada.

Rea, Alexr. 1897. Archaeological Survey of India. New Imperial Series, Volume XXV. Monumental Remains of The Dutch East India Company in The Presidency of Madras. Madras: Printed and Published by The Superintendent, Government Press.

Zuhdi, Susanto. 2002. Cilacap (1830 - 1942): Bangkit dan Runtuhnya Suatu

Pelabuhan di Jawa. Jakarta: KPG (Kepustakaan Populer Gramedia). 